\title{
EVALUASI REAKSI DAN PENGETAHUAN PESERTA TERHADAP MATA PELATIHAN ETIKA PUBLIK
}

\author{
MUNAWAR SHODIQ \\ Widyaiswara Perwakilan BKKBN Provinsi Lampung \\ e-mail: munawar.shodiq1@gmail.com
}

\begin{abstract}
ABSTRAK
Penelitian ini bertujuan untuk mendapatkan gambaran tentang Evaluasi Mata Pelatihan Etika Publik dengan menggunakan Model Evaluasi Kirkpatrick pada Pelatihan Dasar CPNS Kabupaten Tulang Bawang Barat Tahun 2020. Penelitian ini menggunakan metode kuantitatif. Sampel dalam penelitian ini adalah seluruh peserta pelatihan berjumlah 40 orang. Data dalam penelitian ini dijaring dengan menggunakan angket dan evaluasi akademik. Penilaian pada level reaction didapatkan hasil peserta merasa puas terhadap proses pembelajaran, dan penilaian pada level Learning, peserta mendapatkan rata-rata nilai baik. Dengan demikian, hasil penelitian menggambarkan bahwa evaluasi model Kirkpatrick pada Mata Pelatihan Etika Publik diperoleh nilai efektif.

Kata Kunci: Model Evaluasi Kirkpatrick, Etika Publik, Latsar CPNS

ABSTRACT

This study aims to get an overview of the Evaluation of the Public Ethics Training Course using the Kirkpatrick Evaluation Model at the 2020 Basic Training for Civil Servant Candidates for Tulang Bawang Regency. This research uses quantitative methods. The sample in this study were all training participants who accommodated 40 people. The data in this study used a questionnaire and academic evaluation. The assessment of the reaction level shows that the participants are satisfied with the learning process, and the results at the learning level show that participants get a good average score. Thus, the results of the study illustrate that the evaluation of Kirkpatrick's model in the Public Ethics Training Course is effective.
\end{abstract}

Keywords: Kirkpatrick's Evaluation Model, Public Ethics, Latsar CPNS

\section{PENDAHULUAN}

Peningkatan kualitas sumber daya manusia merupakan sesuatu yang sangat penting guna meningkatkan akselerasi suatu pembangunan dalam bidang apa pun. Karena kualitas menyangkut peningkatan mutu sumber daya manusia itu sendiri baik kemampuan fisik maupun kemampuan nonfisik. Pendidikan dan pelatihan merupakan salah satu pendorong untuk meningkatkan kemampuan sumber daya manusiaagar lebih proaktif demi mencapai produktivitas kerja lebih baik.

Aparatur pemerintah sebagai bagian dari sumber daya manusia memiliki peran penting dalam pengembangan tatanan pemerintahan. Oleh sebab itu, aparatur pemerintah diharapkan memiliki kompetensi. Kompetensi yang mumpuni dan sesuai dengan tuntutan publik adala menjadi kewajiban yang harus dimiliki oleh setiap aparatur dalam rangka memperlancar dalam pelaksanaan tugas, pokok dan fungsi, kewenangan dan tanggungjawab sebagai pelayan publik.

Aparatur yang berkompeten merupakan faktor penting, hal ini dikarenakan aparatur memiliki tugas ganda. Disatu sisi aparatur dituntut harus mampu memberikan pelayanan kepada masyarakat secara adil dan profesional, di sisi lain aparatur juga harus menunjukkan loyalitas, dedikasi, dan etos kerja serta integritas yang tinggi. Tugasganda tersebut akan dapat terealisasi manakala didukung dengan kompetensi aparatur yang profesional. Dalam Undangundang Nomor 5 tahun 2014 tentang Aparatur Sipil Negara pada pasal 65 ayat 1 disebutkan bahwa salah satu syarat PNS adalah harus lulus Pendidikan dan Pelatihan. Bukti dari kelulusan tersebut adalah Sertifikat Tanda Tamat Pendidikan dan Pelatihan (STTPP) yang 
diperoleh apabila peserta telah menyelesaikan dua kurikulum, yakni penguatan kompetensi teknis bidang dan penguatan kompetensi teknis bidang tugas. Hal tersebut dipertegas dengan diturunkannya Peraturan Pemerintah Nomor 11 tahun 2017 tentang Manajemen ASN.

Lembaga Administrasi Negara (LAN) selaku Pembinadiklat aparatur melakukan satu bentuk reformasi kediklatan dalam rangka melaksanakan amanat diatas, yaitu dengan melakukan perubahan pola penyelenggaraan Diklat aparatur yang sekarang disebut dengan Pelatihan Dasar CPNS (LATSAR), disertai dengan perubahan kurikulum dan pola pembelajaran menjadi in classdan offcampus serta dengan penekanan pada pembuatan karakter.

Sebagai sebuah program, kebermaknaannya akan efektif jika kegiatan tersebut diakhiri dengan evaluasi.Dalameo manajemen terdapat beberapa fungsi pokok, disamping fungsi perencanaan,fungsi pengorganisasian dan fungsi pelaksanaan, fungsi evaluasi merupakan salah satu diantaranya. Kegiatan evaluasi tersebut telah menjadi bagian tak terpisahkan dari suatu upaya apapun yang terprogram dan tersistematis, tak terkecuali program pelatihan.

Evaluasi merupakan suatu proses yang kontinyu dan menjadi dasar dari keseluruhan kegiatan.Depdikbud (1985) mengatakan bahwa evaluasi merupakan segala usaha membandingkan hasil pengukuran sesuatu materi terhadap patokan yang dibakukan. Hasil pengukuran itu adalah angka atau uraian tentang kenyataan yang menggabikan derajat kualitas materi yang diukur. Sedangkan menurut Arikunto (2003) evaluasi merupakan serangkaian kegiatan atau aktivitas yang bertujuan untuk dapat mengukur tingkat keberhasilan pada suatu program pendidikan. Dengan berdasarkan definisi evaluasi sebelumnya, dapat disimpulkan bahwasecara umum evaluasi dapat diartikan sebagai proses sistematis untuk menentukan nilai sesuatu (tujuan, kegiatan, keputusan, untuk kerja,proses, orang maupun objek)berdasarkan kriteria tertentu. Dalam kegiatan Pendidikan dan Pelatihan, evaluasi dapat didefinisikan sebagai suatu proses sistematik dalam menetapkan tingkat pencapaian tujuan pendidikan dan pelatihan yang telah ditetapkan (Widoyoko, 2019).

Evaluasidalam aktivitas pendidikan dan pelatihan dapat berupa evaluasi hasil belajar dan evaluasi program. Evaluasi hasil belajar lebih difokuskan untuk menilai hasil belajar yang dicapai oleh peserta setelah mengikuti pendidikan dan pelatihan. Sedangkan evaluasi program dilakukan untuk menilai efektivitas dari efisiensi program. Menurut Kirkpatrick (1998) tujuan dari evaluasi adalah untuk mendapatkan informasi yang objektif dan seakurat mungkin tentang suatu program yang telah direncanakan dan sedang dilaksanakan dan atau telah dilaksanakan. Informasi tersebut dapat berupa proses pelaksanaan program, dampak program atau hasil yang dicapai, serta sejauh mana efektivitas dan efisiensi program tersebut. Kemudian hasil dari evaluasi dapat dijadikan sebagai perbandingan dan tolak ukur apakah program tersebut berhasil atau tidak, dapat dilanjutkan atau diberhentikan serta dapat dijadikan pijakan untuk menyusun program lanjutan.

Fink (1995)mendefinisikan program adalah suatu usaha yang sistematis untuk mencapai suatu tujuan yang direncanakan sebelumnya. Hal ini senada dengan pendapat Rutman (1984)dalam yang mengemukakan bahwa program adalah seperangkat kegiatan atau aktivitas yang dirancang untuk mencapai sebuah tujuan. Sedangkan program menurut Sukardi (2015) didefinisikan sebagai suatu kegiatan yang direncanakan dengan seksama, untuk tujuan penting dalam pengambilan keputusan. Sedangkan menurut Arikunto (2010) menjelaskan bahwa program merupakan sistem, dimana sistem adalah satu kesatuan dari beberapa bagian atau komponen program yang saling kait mengkait dan bekerjasama satu dengan yang lainnya untuk mencapai tujuan yang sudah ditetapkan dalam sistem.

Merujuk pada definisi program diatas, dapat disimpulkan bahwa meskipun program diartikan berbeda-beda oleh masing-masing ahli, namun program dapat dipahami sebagai serangkaian kegiatan atau aktivitas sistematis yang direncanakan dan dirancang untuk mencapai tujuan tertentu untuk dijadikan sebagai masukan bagi pengambil keputusan terhadap program yang dievaluasi. Dengan demikian evaluasi program mengandung tiga 
unsur penting yaitu 1) kegiatan sistematis, 2) pengumpulan data dan informasi, dan 3) masukan untuk pengambilan keputusan terhadap program.

Untuk mengevaluasi sebuah program hendaknya memahami bentuk dan makna dari rangkaian kegiatan evaluasi program. Bentuk evaluasi program sangat bermacam-macam dan beragam sehingga mempengaruhi jenis dan model evaluasi. Berbagai model evaluasi telah banyak dikembangkan dan banyak dipakai sebagai strategi atau pedoman kerja dalam pelaksanaan evaluasi program pendidikan dan pelatihan.

Dalam penelitian ini model evaluasi yang digunakan adalah model evaluasi Kirkpatrick (Kirkpatrick four Evaluation Models). Penggunaan model evaluasi ini didasarkan pada kesederhanaan, kelengkapan, kejelasan dan kemudahan dalam mengimplementasikan model tersebut. Model evaluasi yang dikembangkan oleh Kirkpatrick (Widoyoko, 2017: 169) mencakup 4 level evaluasi, yaitu level 1 reaction, evaluasi ini dilakukan terhadap reaksi peserta pelatihan yang bertujuan untuk mengukur kepuasan peserta (customer satisfaction). Program pelatihan dianggap efektif apabila proses pelatihan dirasa menyenangkan dan memuaskan bagi peserta pelatihan sehingga mereka tertarik termotivasi untuk belajar dan berlatih.

Evaluasi level 1 ini tidak mengukur apa yang telah pelajari, namun mengukur minat motivasi dan tingkat perhatian peserta pelatihan.Kirkpatrick menambahkan pentingnya mengukur reaksi, berdasarkan beberapa alasan yaitu untuk memberikan masukan yang berharga kepada penyelenggara pelatihan dalam meningkatkan program pelatihan di masa datang, memberikan saran dan masukan kepada pengajar mengenai tingkat efektivitas mereka dalam mengajar, dapat memberikan informasi kuantitatif kepada para pembuat keputusan terkait dengan pelaksanaan program pelatihan, serta agar dapat memberikan informasi kuantitatif kepada pengajar yang dapat digunakan sebagai dasar untuk membuat standar pengajaran di masa yang akan datang.

Level 2 Learning, evaluasi level ini difokuskan pada perubahan sikap yang terjadi pada saat kegiatan pelatihan dilakukan sehingga lebih bersifat internal. Peserta pelatihan dikatakan telah belajar apabila pada dirinya telah mengalami perubahan sikap, perbaikan pengetahuan maupun peningkatan keterampilan.

Evaluasi level 3 Behavior (evaluasi tingkah laku),evaluasi level ini difokuskan pada perubahan tingkah laku setelah peserta mengikuti pendidikan dan pelatihan, sehingga penilaian tingkah laku ini lebih bersifat eksternal.

Level evaluasi yang terakhir menurut Kirkpatrick adalah level 4 yaitu Result, evaluasi level 4 ini difokuskan pada hasil akhir yang terjadi karena peserta telah mengikuti suatu program. Dalam kegiatan pendidikan dan pelatihan dan ataupun pembelajaran model evaluasi ini mengarah pada hasil akhir yang diperoleh peserta.

Dalam penelitian ini hanya akan menggunakan modelevaluasi Kirkpatrick yang terbatas yaitu hanya pada level 1 dan level 2 padapembelajaran mata pelatihan Etika Publik bagi peserta Pelatihan Dasar (Latsar) CPNSKabupaten Tulang Bawang Barat yang dilaksanakan di Badan Pengembangan Sumber Daya Manusia Daerah (BPSDMD) Provinsi Lampung Tahun 2020.

\section{METODE PENELITIAN}

Penelitian ini merupakan penelitian evaluasi (evaluation research). Penelitian ini dilakukan untuk mendapatkan gambaran tentang Evaluasi Mata pelatihan Etika Publik dengan menggunakan Model Evaluasi Kirkpatrick. Tipe penelitian yang digunakan dalam penelitian ini adalah tipe penelitian deskriptif dengan pendekatan kuantitatif (Sugiyono, 2019). Objek dalam penelitian ini adalah peserta Pelatihan Dasar (Latsar) CPNS Kabupaten Tulang Bawang Barat angkatan IX yang berjumlah 40 orang.

Teknik pengumpulan data dilakukan dengan menggunakan instrumen angket dan evaluasi akademik, disamping observasi/pengamatan, dan dokumentasi (Widoyoko, 2020). Teknik analisis data menggunakan statistik deskriptif. 


\section{HASIL DAN PEMBAHASAN}

\section{Evaluasi Level 1 - Reaksi (Reaction)}

Kepuasan peserta terhadap proses pembelajaran yang dilakukan dikaji dari beberapa aspek, yaitu materi yang diberikan, fasilitas yang tersedia, strategi atau cara penyampaian materi oleh fasilitator (narasumber, widyaiswara) dan media pembelajaran yang tersedia.

Gambaran tingkat kepuasan peserta terhadap proses pembelajaran pada aspek relevansi materi adalah 14 orang atau $30 \%$ peserta menyatakan sangat memuaskan, 24 orang atau $60 \%$ peserta menyatakan memuaskan, 2 orang atau $5 \%$ peserta menyatakan kurang memuaskan. Gambarantingkat kepuasan peserta pada aspek ini bisa dilihat pada gambar 1 dibawah ini:

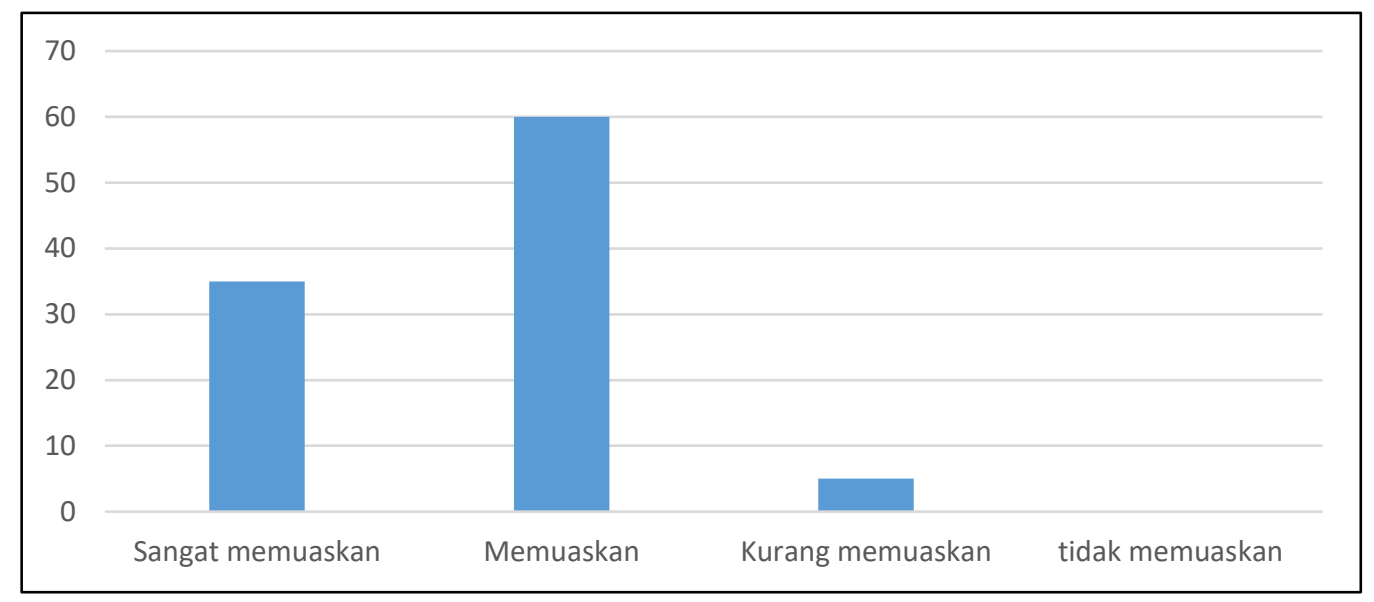

\section{Gambar 1. Reaksi peserta terhadap proses pembelajaran pada aspek materi yang diberikan}

Dari gambar 1 diatas maka dapat dikatakan bahwa peserta yang mengikuti pelatihan pada mata pelatihan Etika Publik memberikan reaksi yang positif terhadap proses pembelajaran dari aspek relevansi materi yang diberikan dengan kategori memuaskan.

Evaluasi ini menjadi acuan untuk melakukan perbaikan ataupun peningkatan dan pengembangan materi atau modul yang disediakan oleh pihak-pihak yang berkepentingan guna mendukung kelancaran proses pembelajaran yang pada akhirnya akan menghasilkan kompetensi yang diharapkan. Kepuasan peserta terhadap proses pembelajaran pada aspek ketersediaan fasilitas yang tersedia adalah 30 orang atau $75 \%$ peserta menyatakanmemuaskan, 10 orang atau $25 \%$ peserta menyatakan kurang memuaskan terhadap fasilitas yang tersedia pada proses pembelajaran. Gambarantingkat kepuasan peserta pada aspek ini dapat dilihat pada gambar berikut ini:

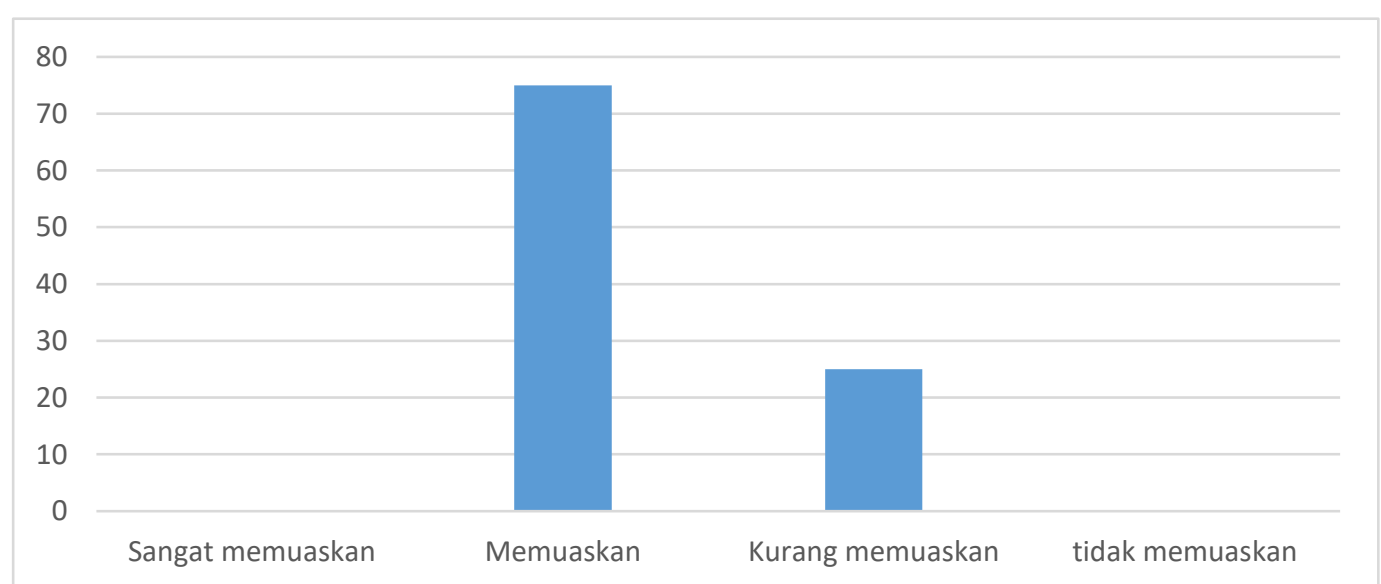

Gambar 2. Reaksi peserta terhadap proses pembelajaran pada aspek fasilitas yang tersedia 
Darigambar 2 di atas dapat disimpulkan bahwa peserta yang mengikuti pelatihan pada mata pelatihan Etika Publik memberikan reaksi yang positif terhadap proses pembelajaran dari aspek ketersediaan fasilitas pembelajaran meskipun belum tersedia dengan lengkap.

Hal ini mengindikasikan perlunya fasilitas yang mendukung suatu program pelatihan, karena ketersediaan fasilitas yang lengkap akan menambah perhatian, semangat peserta dalam proses kegiatan pembelajaran. Ketersediaanfasilitas dalam proses pembelajaran adalah sesuatu yang mutlak diperlukan guna mencapai kompetensi yang diharapkan.

Adapun persentase kepuasan peserta terhadap proses pembelajaran pada aspek strategi atau cara penyampaian materi oleh fasilitator adalah adalah 15 orang atau 37,5\% peserta menyatakan sangat memuaskan, 25 orang atau $62,5 \%$ peserta menyatakan memuaskan terhadap strategi atau cara penyampaian materi oleh fasilitator. Gambaran tingkat kepuasan pada proses pembelajaran pada aspek ini dapat dilihat pada Gambar 3 dibawah ini:

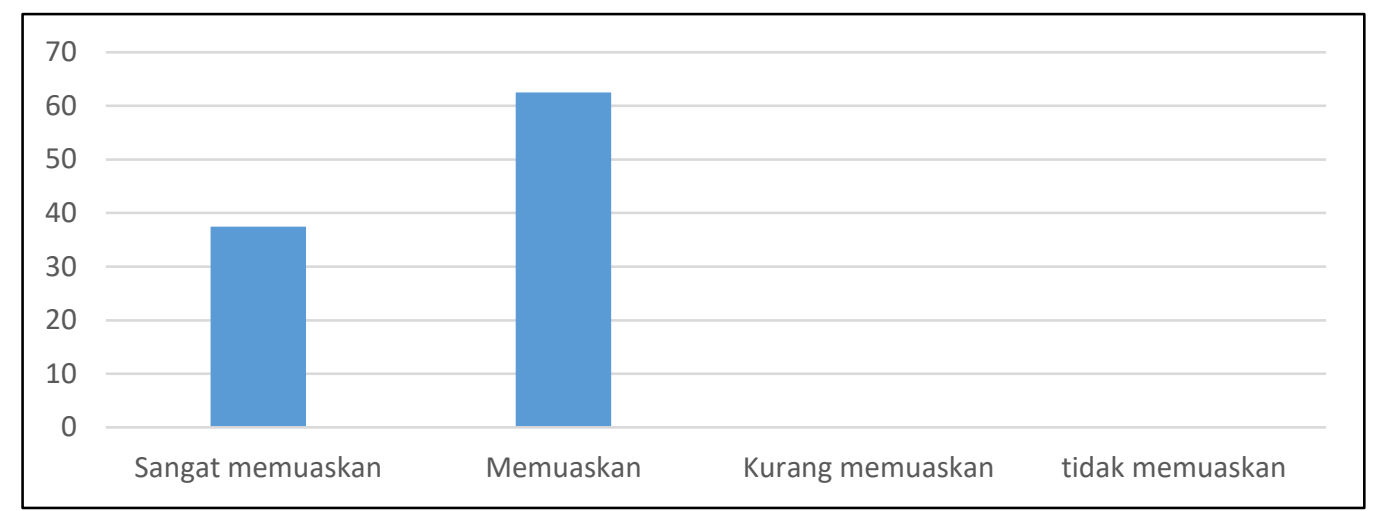

Gambar 3. Reaksi peserta terhadap proses pembelajaran pada aspek strategi/cara penyampaian

Dari gambar 3 di atas terlihat bahwa tingkat kepuasan peserta pada proses pembelajaran pada aspek strategi atau cara yang digunakan fasilitator untuk menyampaikan materi juga mendapatkan reaksi yang positif, namun demikian fasilitator perlu terus mengembangkan kompetensi dan mengupdate pengetahuannyadalam penyempurnaan dan peningkatan kepuasan peserta dalam pembelajaran di masa yang akan datang. Hal ini dikarenakan fasilitator adalah ujung tombak dalam pelaksanaan sebuah program pelatihan. Hasil ini juga menjadi acuan untuk melakukan perbaikan ataupun peningkatan kualitas proses belajar mengajar oleh Widyaiswara atau narasumber.

Tingkat kepuasan peserta pada proses pembelajaran pada aspek media pembelajaran yang digunakan adalah 16 orang atau $40 \%$ peserta menyatakan sangat memuaskan, 23 orang atau $57,5 \%$ peserta menyatakan memuaskan, 1 orang atau $2,5 \%$ peserta menyatakan kurang memuaskan terhadap media pembelajaran yang digunakan oleh fasilitator. Gambaran tingkat kepuasan peserta pada aspek media pembelajaran dapat dilihat pada gambar 4 dibawah ini:

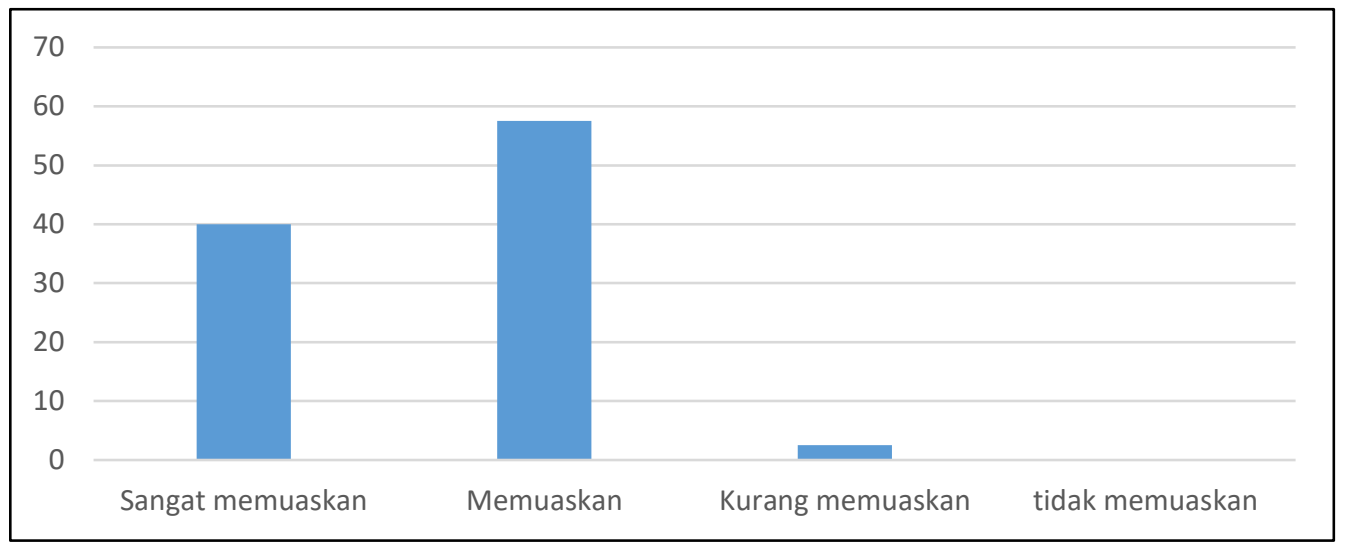

Gambar 4. Reaksi peserta terhadap proses pembelajaran pada aspek media pembelajaran 
Dari gambar 4 di atas dapat dikatakan bahwa peserta yang mengikuti pelatihan pada mata pelatihan Etika Publik memberikan reaksi yang positif terhadap proses pembelajaran yang dilihat dari aspek ketersediaan media pembelajaran.

Sebagai salah satu unsur yang mendukung kelancaran program pembelajaran ketersediaan media tidak bisa diabaikan. Oleh karena itu kenapa pemangku yang berkepentingan harus selalu memperhatikan sarana prasarana pembelajaran dalam hal ini media pembelajaran bila menginginkan pembelajaran yang sesuai dengan apa yang diharapkan.

Sedangkan tingkat kepuasan peserta pada proses pembelajaran pada spek waktu yang digunakan oleh fasilitator adalah 23 orang atau 57,5 \% peserta menyatakan sangat memuaskan, 15 orang atau 37,5\% peserta menyatakan memuaskan, 2 orang atau $5 \%$ peserta menyatakan kurang memuaskan terhadap waktu yang digunakan fasilitator.

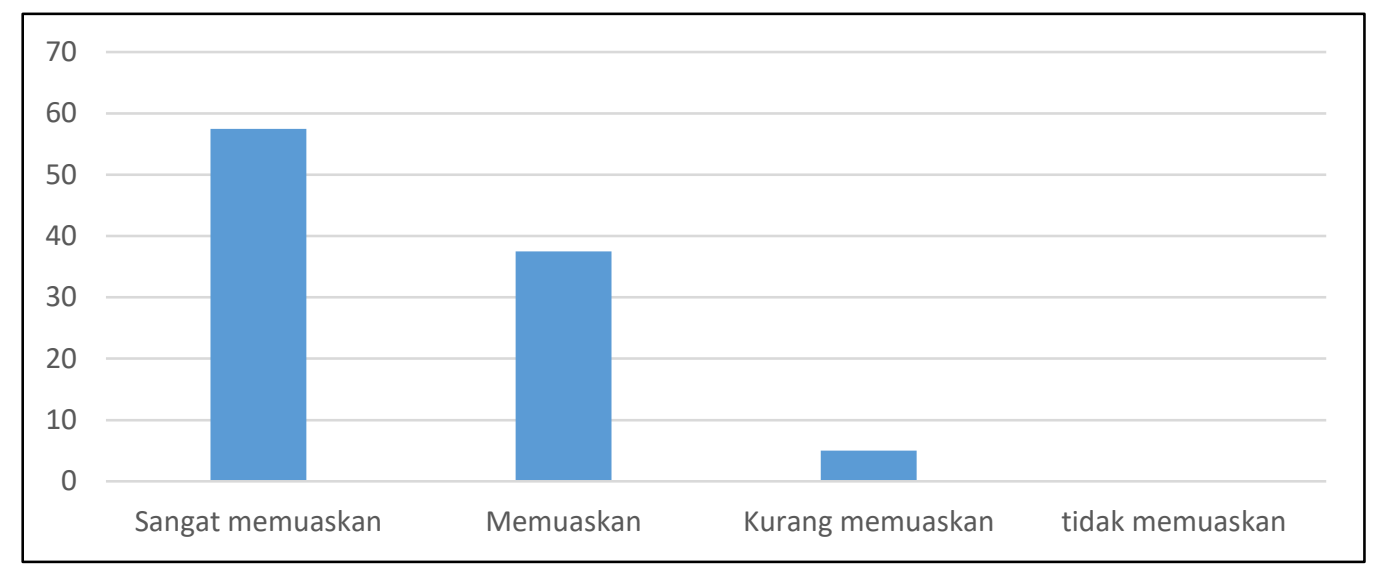

Gambar 5. Reaksi peserta terhadap proses pembelajaran pada aspek waktu yang digunakan

Dari gambar 5 diatas terlihat bahwa reaksi peserta terhadap proses pembelajaran pada aspek waktu yang dimanfaat kan oleh fasilitaor adalah sangat memuaskan.

\section{Evaluasi level 2 - Pembelajaran (Learning)}

Kirkpatrick menyatakan evaluasi di level-2 berhubungan dengan pengukuran tingkat peningkatan kompetensi peserta baik dari segi pengetahuan, keterampilan dan sikap sesuai dengan tujuan diadakan pelatihan. Pembelajarandidefinisikan sebagai prinsip, fakta-fakta dan teknik yang dimengerti dan diserap oleh peserta.

Brinkerhoff (1983) menyatakan bahwa kegunaan evaluasi bertujuan untuk mengukur seberapa baik peserta didik dalam mempelajari pengetahuan atau keterampilan yang disampaikan dalam kegiatan pembelajaran. Menentukansatu hal atau lebih yang berhubungan dengan tujuan pelatihan seperti pengetahuan apa yang telah dipelajari, keterampilan apa yang telah dikembangkan atau ditingkatkan, dan sikap apa yang telah berubah.

Lebihlanjut dikatakan untuk mengukur efektivitas program pembelajaran (Evaluating Learning) menyangkut tiga aspek yaitu perubahan sikap, peningkatan pengetahuan, maupun perbaikan keterampilan pada peserta. Pembelajaranakan dianggap gagal apabila ketiga aspek tersebut tidak terlaksana atau tidak terjadi perubahan. Penilaianevaluasi learning lebih mengarah pada penilaian hasil (output) belajar.

Pembelajaran mata pelatihan Etika Publik dilakukan dengan harapan untuk mengembangkan dan memberikan bekal kepada peserta dalam melakukan tugas dan fungsinya sebagai pelayan publik yang profesional. Evaluasipembelajaran peserta dilakukan untuk mengetahui penguasaan peserta terhadap konsep mata pelatihan, penalaran peserta secara individu. 


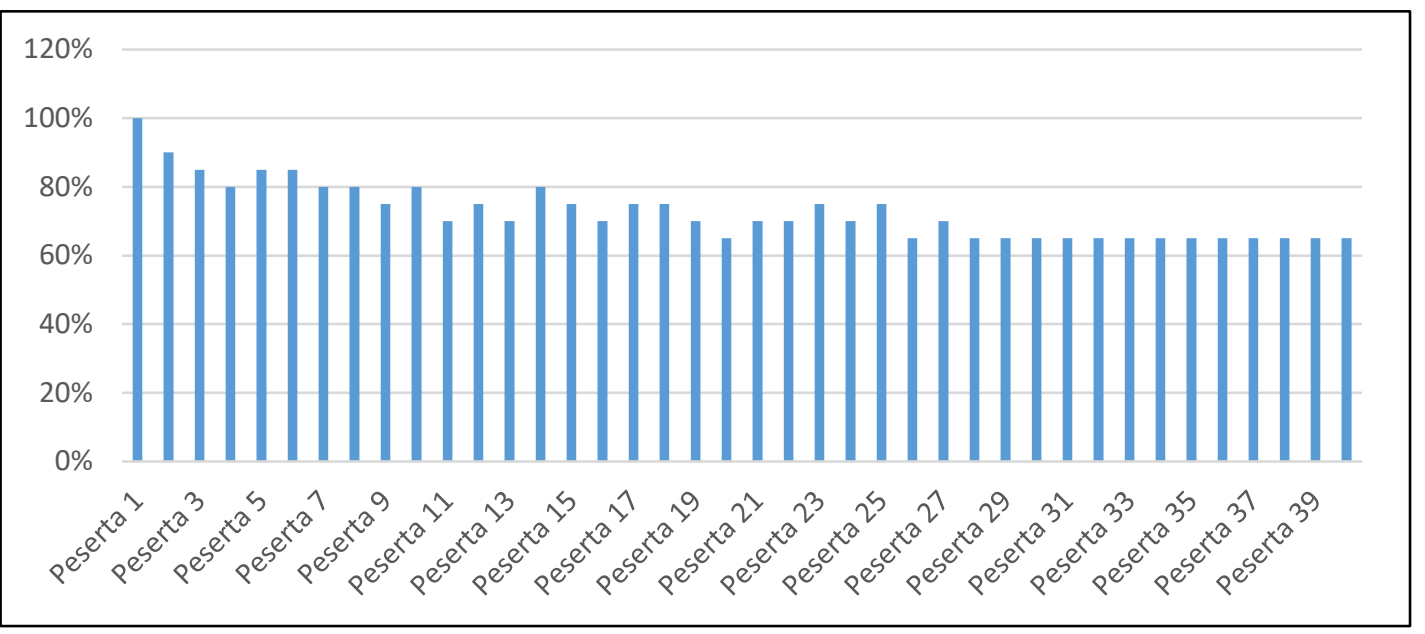

Gambar 6. Hasil penilaian peserta

Dari gambar 6 diatas dapat dilihat bahwa nilai tertinggi yang diperoleh adalah sebesar 100 dan nilai terendah yang diperoleh sebesar 65. Sedangkan rata-rata niai peserta pelatihan adalah sebesar $73 \%$. Hal ini menunjukkan bahwa kemampuan peserta pelatihan Latsar CPNS angkatan 9 pada mata pelatihan Etika Publik masuk kategori baik.

Level kedua yang diukur adalah aspek pembelajaran peserta yang berkaitan dengan pengetahuan. Pada level kedua peserta yang mengikuti mata pelatihan Etika Publik dinilai kemampuan dan pengetahuan melalui evaluasi akademik Hal ini dilakukan untuk mengetahui semua potensi yang dimiliki oleh peserta.

Levelkedua pada evaluasi model Kirkpatrick menjabarkan aspek-aspek penilaian secara menyeluruh dan kriteria penilaian yang jelas. Kriteria inimenunjukkan pemahaman terhadap konsep mata pelatihan Etika Publik yang diukur pada tingkat penguasaan konsep. Penguasaan konsep sangat bermanfaat bagi peserta sebagai bekal untuk dalam menjalankan tugas dan kewajibannya selaku ASN sebagai pelayan yang profesional.

Berdasarkan hasil analisis data menggambarkan Evaluasi Mata Pelatihan Etika Publik dengan menggunakan Model Evaluasi Kirkpatrick pada Pelatihan Dasar CPNS Kabupaten Tulang Bawang Barat Tahun 2020 berjalan sesuai dengan yang diharapkan dan dapat memberikan gambaran tentang kemampuan peserta secara keseluruhan. Pada level 1 Reaksi yang dilihat dari aspek materi yang diberikan, fasilitas yang tersedia, strategi atau cara penyampaian materi oleh fasilitator (narasumber, widyaiswara) dan media pembelajaran yang tersedia rata-rata peserta pelatihan memberikan nilai memuaskan.

Sedangkan pada level 2 Pembelajaran, para peserta memperoleh nilai yang baik bahkan ada peserta yang mendapatkan nilai sempurna.

\section{KESIMPULAN}

Dari hasil pembahasan diatas, menunjukkan bahwa Evaluasi Mata Pelatihan Etika Publik dengan Menggunakan Model Evaluasi Kirkpatrik pada Pelatihan Dasar CPNS Kabupaten Tulang Bawang Barat tahun 2020 dikategorikan efektif. Hal ini bisa dilihat dari pengukuran efektivitas level 1 dan level 2 model Kirkpatrick. Pada level 1 reaction peserta terhadap proses pembelajaran diperoleh rata-rata reaksi yang memuaskan. Sedangkan dilihat pada level 2 dari aspek learning, pengetahuan peserta dalam memahami konsep mata pelatihan terbilang baik hal ini bisa dilihat dari nilai yang diperoleh peserta pelatihan.

Tidak ada penelitian yang mencakup semua aspek. Begitu juga dengan penelitian ini, dari 4 aspek pengukuran efektivitas yang dikemukakan oleh Kirkpatrick, baru 2 tahap yang digunakan oleh peneliti. Sedangkan untuk level 3 behavior dan level 4 result belum dilakukan peneliti. Berangkat dari hal tersebut, peneliti berharap ada penelitian lanjutan untuk melihat behavior dan result dari pelatihan. 


\section{DAFTAR PUSTAKA}

Arikunto, Suharsimi. 2010. Evaluasi Program Pendidikan. Jakarta: Bumi Aksara.

Brinkerhoff, R.O. 1983. Program Evaluation: A Practitioner"s guide for trainers and educators. Western Michigan: Kluwer-Nijhoff.

Departemen Pendidikan dan Kebudayaan. 1985. Penilaian dalam Pendidikan Program Akta. Mengajar V. Jakata: Universitas Terbuka.

Fink, Arline. 1995. Evaluation for Education and Psychology. London: Sage Publication.

Kirkpatrick, D. L. 1998. Evaluating Training Programs: The Four Levels. San Francisco: Berrett-Koehler Publisher, Inc.

Peraturan Kepala LAN RI Nomor 21 tahun 2016 tentang Pedoman Penyelenggaraan Pelatihan Dasar Calon PNS.

Peraturan Pemerintah Nomor 11 tahun 2017 tentang Manajemen ASN

Rutman, Leonard. 1984. Evaluation Research Methods: A Basic Guide. London: Sage Publication.

Sugiyono. 2019. Metode Penelitian Kuantitatif, Kualitatif, dan R\&D. Bandung: Alfabeta.

Sukardi. 2015. Evaluasi Program Pendidikan dan Penelitian. Bandung: Bumi Aksara.

Undang-undang nomor 5 tahun 2014 tentang Aparatur Sipil Negara

Widoyoko, E. P. 2017. Evaluasi Program Pelatihan. Yogyakarta: Pustaka Pelajar.

Widoyoko, E. P. 2019. Evaluasi Program Pembelajaran: Panduan Praktis Bagi Pendidik dan Calon Pendidik. Yogyakarta: Pustaka Pelajar.

Widoyoko, E. P. 2020. Teknik Penyusunan Instrumen Penelitian. Yogyakarta: Pustaka Pelajar. 